\title{
A METAFÍSICA - POLO DE DISCUSSÃO ENTRE HEIDEGGER E CARNAP
}

\author{
FLÁVIO DE OLIVEIRA SILVA ${ }^{1}$
}

RESUMO: No encontro de Davos de 1929 na Suíça entre Heidegger e Cassirer, Carnap presenciou a conferência de Heidegger de título $O$ que é metafísica, na qual o filósofo defendia uma interpretação antilógica e anti-neokantiana para o sentido de metafísica, presente na Crítica da Razão Pura (1994) de Kant. Após esse encontro, Carnap voltou a Viena, estudou atentamente o tratado Ser e Tempo (1998) e no ano seguinte escreveu um esboço do artigo "A superação da metafísica pela análise lógica da linguagem", com versão definitiva publicada em 1932. Desde então a superação da metafísica se tornou um termo recorrente para expressar a crítica à metafísica. Pretende-se explicitar pontos convergentes entre Heidegger e Carnap sobre a concepção de metafísica e apontar como divergência entre ambos, a pretensão almejada com a superação da metafísica. Tem-se em vista, como ponto de divergência na discussão, o posicionamento de cada um acerca do império da lógica e das ciências exatas.

PALAVRAS-CHAVE: Heidegger; Carnap; Metafísica; Superação da metafísica; Überwindung.

ABSTRACT: In 1929 Davos meeting in Switzerland between Heidegger and Cassirer, Carnap watched the conference of Heidegger, about the theme What is metaphysics, in which the philosopher defended an anti-logical interpretation and anti-neo-Kantian to the meaning of metaphysics, in the Critique of Pure Reason (1994) of Kant. After this meeting, Carnap returned to Vienna, studied carefully the treaty Being and Time (1998) and the following year he wrote a sketch of article "The overcoming of metaphysics by logical analysis of language", with the final version published in 1932. Since then the overcoming of metaphysics became a recurring term to express criticism of metaphysics. It is intended to explain convergence between Heidegger and Carnap about the meaning of metaphysics and to show yet, points of disagreement between the two, present in pretension of overcoming of metaphysics. It is also intended emphasize the position of each about the empire of logic and of exact sciences, and finally, a brief analysis about the term Überwindung.

KEYWORDS: Heidegger, Carnap; Metaphysics; Overcoming of metaphysics; Überwindung.

Desde o século passado, sobretudo a partir dos anos 30, tem sido recorrente na filosofia, análises e discussões sobre o tema "superação da metafísica" (Überwindung der Metaphysik). Esta expressão agrega dois temas extremamente discutíveis na filosofia: metafísica (Metaphysik) e superação (Überwindung). O primeiro tema está presente desde o início da história da filosofia e tem em Aristóteles aquele que de forma sistemática caracterizou esse modo peculiar de saber, ora como ciência primeira, ora como filosofia primeira. Em ambas as referências, Aristóteles a concebe como um saber, cuja área específica de investigação tem como tarefa estudar o ente enquanto ente naquilo que corresponde ao seu 
$\operatorname{ser}^{2}$. Ainda conforme Aristóteles, essa ciência primeira corresponde à filosofia como ciência da verdade ${ }^{3}$. Na indicação do estagirita, caberia a essa ciência primeira ou filosofia primeira ${ }^{4}$, posteriormente designada "metafísica", investigar acerca dos princípios mais verdadeiros, isto é, dos princípios primeiros aos quais não lhes podem ser atribuídos nenhuma causa, posto que, esses princípios são propriamente a causa de ser para as demais coisas ${ }^{6}$. A partir desta primeira sistemática tematização sobre a metafísica, seguiram-se inúmeras discussões, e estas se confundem com a própria história da filosofia. Não é nossa pretensão a exposição histórica do tema, senão no ponto específico para o qual sinaliza o título deste artigo.

Quanto ao surgimento do tema superação (Überwindung), na sua relação à metafísica, esta tem sua incursão explícita na filosofia, a partir do século passado. O tema se tornou questão guia na discussão contemporânea sobre a temática filosofia, ciência e conhecimento e reivindica, como pano de fundo para discussão, colocar em questão as condições de possibilidade sobre as quais se caracterizaria a validade do conhecimento enquanto saber.

A partir da requisição tácita da superação da metafísica seguiram-se diversos posicionamentos sobre o tema em questão. Paralelamente e em razão dessa discussão, o termo "superação" despontou como questão, cuja semântica precisou ser problematizada, a fim de esclarecer e dar a conhecer o âmbito da principal voz discursiva da contemporaneidade, a saber, Martin Heidegger, a reivindicar a superação da metafísica.

Minuciosas exegeses morfológicas seguiram-se em torno da partícula Windung que compõe o termo Überwindung, contudo, tal esforço soma ganhos de clareza, quando associado ao modo e circunstâncias em que tacitamente o termo superação da metafísica (Überwindung der Metaphysik) surge na filosofia.

Visto esta sucinta consideração inicial sobre os temas: "metafísica" e "superação", convém adentrarmos propriamente no tema proposto.

Ao designarmos a metafísica como polo de encontro entre Martin Heidegger e Rudolf Carnap, pretendemos indicar, a despeito das divergências existentes entre ambos os posicionamentos, a discussão sobre o tema metafísica como coalizão entre os dois filósofos supracitados em duas perspectivas: o tema da metafísica como questão sobre a qual os dois filósofos reivindicam a superação da metafísica como condição de possibilidade para o rigor do pensamento, e ainda, pelo fato de ambos comungarem de certa concordância sobre o significado de metafísica. 
O termo Superação da metafísica é recorrente nos textos de Heidegger, mas ele não foi o primeiro a utilizá-lo. O termo surge pela primeira vez em 1932 no artigo $A$ superação da metafísica pela análise lógica da linguagem (Überwindung der Metaphysik durch logische Analyse der Sprache) de Rudolf Carnap ${ }^{7}$. Esse artigo tem importância capital, tanto pelo que provocou no pensamento de Heidegger como pelo fato de ter sido uma resposta de Carnap em torno da preleção $O$ que é metafísica? (Was ist Metaphysik?), pronunciado por Heidegger em 1929, no encontro de Davos entre Heidegger e Cassirer, no qual Carnap era um dos ouvintes (FRIEDMAN, 2004). Desde então, o termo superação da metafísica se torna recorrente na produção de Heidegger e se estende para além dos domínios de sua produção, multiplicando especulações acerca do seu significado na esfera do pensamento do filósofo e na filosofia em geral.

O termo Überwindung tem sido analisado e discutido tanto para demarcar a diferença entre o empenho de Carnap e o de Heidegger, como para demarcar a diferença entre a proposição de Heidegger e aquela pronunciada por Hegel, mediante a palavra alemã aufhebung na Ciência da Lógica ${ }^{8}$. O próprio Heidegger se ocupou em esclarecer a peculiaridade do termo Überwindung na diferença às demais requisições de superação, tendo ainda se utilizado de termo homônimo Verwindung para igualmente esclarecer seu sentido de superação.

Conforme delimitação deste artigo, nosso propósito visa retomar a discussão no âmbito de domínio do pensamento de Heidegger e Carnap. Nesta perspectiva, ao intentarmos uma exposição do enfoque dado ao termo Überwindung na leitura heideggeriana, mostra-se fundamental destacar nesta apresentação que o sentido de metafísica para Heidegger se desenvolve em atenção às suas posições fundamentais ${ }^{9}$.

O ganho em tratar dos diferentes termos que aparentemente aludem a uma mesma coisa: Überwindung, Aufhebung ou Verwindung se potencializa na medida em que a metafísica em seu conteúdo é posto em questão. O uso do termo superação da metafísica na via pretendida por Heidegger, continuadamente precisa explicar que a superação por ele requisitada não é do âmbito daquela pretendida por Carnap, no sentido de negação e refutação da metafísica. No sentido heideggeriano de superação da metafísica não se pretende extinguila, nem descaracterizá-la. O âmbito desta superação pressupõe a desconstrução de paradigma, dogmas e postulados constitutivos da metafísica, sem, no entanto, a pretensão de refutá-la ou negá-la como pretendeu Carnap. Na requisição heideggeriana a superação da metafísica deve 
garantir a compreensão dos limites da metafísica e a delimitação do seu domínio na história do pensamento.

Conforme Heidegger, mediante a superação da metafísica, o pensamento atenta, a partir de então, para o pensar que se inaugura em uma dimensão fora do âmbito de controle e efetivação da metafísica e, por isto, lhe é desconhecido. A superação da metafísica é, em última instância, o abandono da interpretação metafísica da metafísica.

Apesar de Heidegger ter se apropriado do termo superação da metafísica (Überwindung der Metaphysik) utilizado por Carnap, sua pretensão foi comunicar uma requisição diferente daquela proposta por Carnap.

Uma das motivações para o já referido artigo de Carnap, "A superação da metafísica pela análise lógica da linguagem" (Überwindung de Metaphysik durch logische Analyse der Sprache $)^{10}$, foi o já nomeado encontro em Davos na Suíça, em 1929, entre Heidegger e Cassirer, no qual Carnap era um dos ouvintes.

No referido encontro os dois conferencistas, Heidegger e Cassirer discutiram o significado de metafísica e se empenharam em explicitar e defender um sentido específico da pretensão kantiana para o termo "meta" de metafísica. O tema da transcendência foi, portanto, a questão específica em pauta.

Enquanto Cassirer defendia o trans, isto é, o ultrapassamento da sensibilidade, como atributo da espontaneidade, concebendo-o vinculado à liberdade do sujeito kantiano, objetividade e absolutismo da dimensão prática. Heidegger, por sua vez, interpretava o trans no sentido da imanência à experiência, receptividade e finitude. Ele criticou a posição de Cassirer considerando seu ponto de vista recorrente, unidirecional e de interpretação negativa da metafísica, próprio do neokantismo ${ }^{11}$.

A interpretação de Heidegger acerca da filosofia transcendental de Kant era formulada em âmbito inteiramente diverso daquele defendido pelos neokantianos. Enquanto os neokantianos concebiam o problema da fundamentação do saber como questão a ser investigada por meio da teoria do conhecimento, entendendo a Crítica kantiana nesse viés, Heidegger por sua vez não concebia a epistemologia como um saber capaz de explicar a origem do conhecimento. Em divergência a esta concepção do neokantismo, o filósofo interpretou a Crítica da Razão Pura (1994), de Kant, como uma exposição investigativa, cujo alcance ultrapassava os limites de uma teoria do conhecimento ${ }^{12}$.

Dois aspectos devem ser enfatizados nessa interpretação heideggeriana: a epistemologia não dispõe das condições de possibilidade para explicar a origem do 
conhecimento; a Filosofia Transcendental não se apresenta como uma teoria do conhecimento, mas como a verdadeira filosofia, isto é, como fundação da metafísica ${ }^{13}$.

Ao conceber a Filosofia Transcendental de Kant como "fundação da metafísica", Heidegger considerou a Crítica kantiana uma destruição dos fundamentos da metafísica tradicional, tendo se seguido a essa destruição o reposicionamento das reais condições de possibilidade da metafísica ${ }^{14}$.

Conforme Heidegger, o transcendentalismo kantiano se apresenta como uma espécie de desentrave investigativo que eliminou a distinção até então instituída entre coisa em si e fenômeno. Neste sentido, o fenômeno passa a ser interpretado como manifestação positiva da essência da coisa (HEIDEGGER, 2002). Tendo em vista essa via de interpretação, Heidegger então considerou que a doutrina kantiana do conhecimento deveria ser interpretada como ontologia.

No encontro de 1929 em Davos, Heidegger, portanto, expressa suas considerações à Filosofia Transcendental de Kant, na linha de questionamento em que já havia afirmado ter desenvolvido sua obra Ser e Tempo $(1998)^{15}$ (Sein und Zeit).

Assim, no encontro de Davos, Carnap pôde presenciar o pronunciamento de Heidegger e sua interpretação antilógica e anti-neokantiana de Kant, o que o deixou, segundo Friedman (2004), profundamente abalado. Ainda conforme Friedman, após esse encontro, Carnap voltou a Viena, estudou atentamente o tratado Ser e Tempo e no ano seguinte de 1930, participou de um grupo de estudo junto com Gompertz e Bühler ${ }^{16}$, no qual o livro de Heidegger foi estudado e colocado em discussão. Neste mesmo ano Carnap escreveu um esboço do já referido artigo e o apresenta em diversas universidades entre 1930 e 1931. Em 1932 publicou a versão definitiva.

$\mathrm{O}$ artigo de Carnap, no item 5 de título: Pseudoenunciados metafísicos (Metaphysische Scheinsätze), contém uma série de exemplos tratados na preleção heideggeriana de 1929. Nesse item Carnap afirma que os enunciados metafísicos estão no âmbito da ficção:

Consideremos agora alguns exemplos de pseudoenunciados metafísicos de uma espécie onde a violação da sintaxe lógica é particularmente óbvia, embora estejam de acordo com a sintaxe gramatical tradicional. Selecionamos algumas sentenças de uma escola metafísica que atualmente exerce grande influência na Alemanha. "Só o Ser deve ser investigado - e nada mais; o Ser isolado e mais - nada; apenas o Ser, e além do Ser, nada. O que dizer desse Nada? [...] Que o nada existe apenas porque o Não, isto é, a Negação, existe? Ou acontece o contrário? A Negação e o Não existem 
apenas porque o Nada existe? [...] Dizemos: o Nada é anterior ao Não e à Negação. [...] Onde encontramos o Nada? Como encontramos o Nada. [...] Conhecemos o Nada. [...] A angústia revela o Nada. [...] Aquilo por qual e pelo qual estávamos angustiados era "realmente" - nada. De fato: O Nada em si mesmo - como tal estava presente. [...] O que dizer desse Nada? - O Nada nadifica"].

[As citações seguintes (as originais estão em itálico) foram retiradas de $\mathrm{M}$. Heidegger, Was ist Metaphysik?, 1929. Poderíamos ter selecionado passagens de qualquer outro dos numerosos metafísicos do presente ou do passado; mesmo assim, as passagens selecionadas parecem-nos ilustrar bem nossa tese. (N. do A.)]. (CARNAP, 2009, p.300).

Friedman faz uma constatação interessante ao estabelecer um comparativo entre a concepção de metafísica de Heidegger, no texto de 1929, e a concepção de metafísica de Carnap. Segundo Friedman, a concepção de metafísica no texto de Heidegger - O que é metafísica? (1996) - e no texto de Carnap sobre a superação da metafísica, coincidem. Para Carnap, a metafísica é o âmbito do conhecimento da essência das coisas que transcende ao conhecimento das ciências fundadas empiricamente. Friedman considera que Carnap segue no mesmo entendimento de Heidegger. A diferença entre ambos reside na divergência de pretensão.

Carnap apresenta esse conceito na pretensão de negativizar a metafísica, isto é, desconsiderar o âmbito da metafísica. Ele considera o conteúdo da metafísica de natureza fictícia, desprovido de qualquer validade.

Heidegger expressa seu posicionamento em defesa da metafísica. Ele considera a metafísica um saber que transcende a causa material e, por isto, nem a lógica matemática e nem as ciências exatas são capazes de decidir coisa alguma sobre o seu conteúdo. Com esta exposição, Heidegger estabelece uma polêmica contra o império da lógica e das ciências exatas.

Conforme Friedman (1996), enquanto Heidegger, com base no a priori kantiano, estava obstinado no texto de 1929 a derrubar a autoridade e a primazia da lógica e das ciências exatas, Carnap, por sua vez, estava determinado a todo custo a defender essa autoridade e primazia. Ainda, segundo Friedman, a repercussão da crítica de Carnap à metafísica, publicada em artigo, teria conduzido Heidegger a problematizar a metafísica e passar a recepcioná-la em viés negativo, reconhecendo esse saber como questão acerca da qual o pensamento deve meditar.

Segundo Friedman, Heidegger tinha conhecimento das críticas de Carnap lançadas contra a metafísica. Conforme o autor, Heidegger cita a revista Erkenntnis e, em particular, o artigo de Carnap em uma passagem da Introdução à metafísica (Einführung in die Metaphysik), preleção do semestre de verão de 1935, na qual o filósofo acusa a revista de 
representar um modo de pensar que oculta o significado da verdade como abertura e a reduz a mera certeza (FRIEDMAN, 1996) ${ }^{17}$. Ainda, segundo Friedman (2004), a partir da preleção supracitada, Heidegger começa a usar o termo superação da metafísica (Überwindung der Metaphysik) para designar o próprio programa filosófico, cuja pretensão, sabemos, é diversa da pretensão de Carnap.

"A superação da metafísica" (Überwindung der Metaphysik), termo homônimo àquele utilizado por Carnap, é também o título do artigo de Heidegger escrito entre os anos de 1936 a 1946 e publicado no livro Ensaios e conferências (Vorträge und Aufsätze) em 1954. Conforme já mencionado, a requisição heideggeriana tem um propósito diferente daquele pretendido por Carnap, apesar do filósofo ter se servido do mesmo termo superação da metafísica (Überwindung der Metaphysik).

Quase um século depois da formulação expressa da superação da metafísica, ainda nos parece estranha a escolha de Heidegger para nomear o seu projeto filosófico da maturidade. Sua proposta de superação da metafísica é tratada em diversas perspectivas, de modo que não se pode precisar, nem avaliar o todo desse projeto heideggeriano, senão em pontos específicos e localizados. Tal dificuldade provavelmente concorreu para arrefecer na atualidade a discussão do tema superação, antes efervescente.

Em todo caso, estamos inclinados a considerar como uma das dificuldades iniciais enfrentadas no programa filosófico de Heidegger a nomeação pelo termo Überwindung. Consideramos inadequado o referido termo para a pretensão heideggeriana, tendo em vista seu viés oposto ao de Carnap, mas, sobretudo em decorrência da etimologia para o qual o termo nos remete.

O uso deste termo para a pretensão de Heidegger tende mais a dificultar e embaraçar o acesso imediato à sua filosofia, do que propriamente nomear devidamente a sua pretensão. O termo Überwindung não aponta devidamente para a via pretendida por este filósofo, cujo sentido de superação é atípico em relação ao que o termo superação nos envia. A superação defendida por Heidegger se dá na medida em que, em lugar de deixar para trás o que se pretende superar, caracteriza-se por ser um deter-se sobre aquilo que precisa ser superado e que por sua vez nunca é e nem pode ser deixado para trás, ao contrário, permanece vigente (HEIDEGGER, 2001), o que significa dizer que se trata de um movimento em que de fato o termo "Überwindung der Metaphysik", utilizado por Heidegger, não se mostra suficiente para comunicar a sua pretensão. 
Por tais motivos, a escolha de Heidegger requisita o levantamento do ambiente e origem do termo. Mediante essa devida atenção, compreendem-se as possíveis motivações pelas quais se utilizou de um termo, cujo significado diverso da peculiaridade que reivindica, tenha sido empregado por um filósofo que sempre requisitou esmero e trato com as palavras no pronunciamento do pensamento.

Especialistas no pensamento de Heidegger tentaram justificar uma possível correspondência entre o termo superação e a proposta do filósofo. Para justificar o seu uso, lançam mão da etimologia. Em uma dessas tentativas é explorado o significado da palavra Windung que compõe o termo "Überwindung", apresentando-o como "giro", defendido no sentido de um "voltar-se sobre si mesmo". Segundo esta interpretação, o uso do termo superação (Überwindung) deveria conduzir o leitor para vislumbrar esta tarefa do voltar-se do pensamento para aquilo que deseja superar, no caso, a metafísica, conforme explicação dada pelo tradutor do texto de Heidegger $A$ superação da metafísica (Die Überwindung der Metaphysik) ${ }^{18}$.

[...] toda superação envolve um voltar-se sobre esta coisa mesma e uma apreensão dela em sua determinação própria. $\mathrm{O}$ voltar-se sobre a coisa a ser superada não pode representar, contudo uma permanência junto a ela. O voltar-se sobre a coisa prossegue assim em um retorno ao solo mesmo da superação. Temos aí então um giro completo (HEIDEGGER, 2000, p. 187)

Evidentemente essa justificação para o termo superação (Überwindung) nos parece forçada. O termo "Windung" em seus vários sentidos em alemão significa: volta, circunvolução, enrolamento, rosca, curva, sinuosidade (HOEPNER ; KOLLERT ; WEBER, 2001, p. 1195) e não mais que isso. Dito isto, o termo "Windung" não comporta um sentido reflexivo enquanto algo que se volta sobre si mesmo e possa apontar em outra direção. Dar esta conotação ao pensamento sobre o termo Überwindung proposto por Heidegger pode ser admissível, porém, constitui uma violação atribuir esse sentido como próprio e imanente ao termo.

Obviamente Heidegger deve ter percebido esta dificuldade e concluído que o termo superação (Überwindung) não exprime devidamente o sentido de ultrapassamento que ele tem em mente e requisita. Certamente não foi por acaso que o filósofo se utilizou de outros termos para exprimir sua pretensão. Conforme se pode ver no posfácio adicionado à preleção de 1943, em $O$ que é metafísica? Heidegger afirma que a superação (Überwindung) é essencialmente uma passagem (Übergang). Uma passagem por intermédio da metafísica em 
que o ser mesmo não se deixa representar. Verwindung é outro termo utilizado pelo filósofo no texto A superação da metafísica para comunicar sua pretensão. Conforme Vatimo, seu significado não é preciso, mas segue na direção dada pelos tradutores franceses da obra Ensaios e conferências, na indicação de um ultrapassamento que tem como característica “aceitação e aprofundamento" (VATTIMO, 2011, p.180). Como se pode ver, o termo superação utilizado por Heidegger mais obscureceu a pretensão do filósofo do que propriamente tenha dado luz à questão.

Por diversas vezes Heidegger se queixou das limitações apresentadas na linguagem metafísica para comunicar o seu pensamento. Essa alegação é questionável como justificativa para o uso do termo superação, mesmo no âmbito da metafísica. Não é tarefa neste artigo o exame da questão da linguagem e do seu emprego nos escritos de Heidegger, cabe, todavia o referido registro e uma pergunta vazia, dada a impossibilidade de se precisar uma reposta: teria a nomeação do seu projeto no termo superação um propósito pedagógico? Embora o ambiente discursivo heideggeriano contemple a linguagem como a casa do ser no sentido de ser ela, a linguagem, o que propicia as categorias do pensamento e não ao contrário, como querem e pensam os analíticos, temos que questionar a autoridade com a qual se impõe ao termo Überwindung comportar ambiguidade e imprecisão para ser capaz de comunicar o projeto filosófico de Heidegger no sentido de um superar que não deixa para trás o superado.

Carnap havia denunciado ausência de significado aos enunciados metafísicos. Afirmou que em sentido estrito, uma sequência de palavras é sem significado se não constitui, dentro de uma linguagem específica, um enunciado. Segundo o autor, na metafísica uma sequência de palavras podem até constituir um enunciado, mas apenas aparentemente, isto é, como pseudoenunciados. (CARNAP, 2009).

Ainda conforme o autor, o significado de uma palavra pressupõe que a sintaxe da palavra esteja fixada, assim como ela aparece em sentença simples. Para dar uma demonstração da falta de rigor dos metafísicos ele cita alguns exemplos recorrentes na metafísica, dentre os quais o termo "princípio", para então perguntar pelo seu critério de aplicação ou definição.

Se refletirmos sobre o significado original da palavra "principium" (e da palavra grega correspondente " $\alpha \rho \chi \eta$ ") notaremos o mesmo desenvolvimento. Apalavra é explicitamente desprovida de seu significado inicial de "origem" não significa algo que não teve um instante anterior no tempo, mas algo anterior em algum outro sentido, de aspecto metafísico. Falta, no entanto, o critério para esse "aspecto metafísico". (CARNAP, 2009, p. 297) 
Carnap conclui que a palavra principium e seu correspondente em grego não contemplam o seu significado original antes mesmo de ser dado um novo significado, de modo que a palavra permanece como uma concha vazia. (CARNAP, 2009).

É certo que a interpretação de linguagem em Carnap é inteiramente diversa daquela concebida por Heidegger. $\mathrm{Na}$ análise lógica da linguagem empreendida por Carnap, a linguagem é reduzida a um domínio instrumental, a uma ferramenta, a uma propriedade cujos critérios rígidos de aplicação já estão previamente determinados. Todavia, conforme já sinalizado, os critérios apresentados por Carnap em seu texto não podem servir de critério para aferir validade ou rigor aos enunciados metafísicos, haja vista o âmbito da metafísica não se confundir com o âmbito das ciências, cujo emprego das palavras tem ressonância empírica. Em vez disso, a metafísica trata de temas que transcendem ao conhecimento das ciências fundadas empiricamente e em sendo assim, a linguagem que trata tais temas não poderia meramente se reduzir a um instrumento. No entanto, isso não significa que a metafísica não disponha de "critérios" ou não as observe na elaboração de seus enunciados. Certo rigor no uso das palavras também precisa estar garantido na metafísica.

É sabido que Heidegger por diversas vezes resignificou termos recorrentes na filosofia, na pretensão de comunicar o seu pensamento. Palavras como "existência", "essência", "ser", "natureza", entre outras, sofreram resignificação da parte do filósofo. Dois aspectos mostram que essas resignificações não foram aleatórias: a referência ao seu significado original e a observância à sua sintaxe, isto é, à estrutura da palavra no que concerne à forma como ela condiciona o todo do enunciado. Ambos os aspectos são amplamente tematizados na análise que Heidegger faz dessas palavras da origem.

Termos como os acima citados são nomeados por Heidegger como "palavras da origem", tanto em referência ao pensar como em referência ao surgimento da filosofia que funda a via do pensamento ocidental.

Nesta perspectiva, pode-se dizer que a resignificação heideggeriana dessas palavras tomam como referência a concordância com o seu sentido original e originário ${ }^{19}$, de modo que podemos considerar essa concordância como um critério lógico no âmbito dos enunciados metafísicos heideggeriano.

A partir do que foi dito, temos em mente poder finalizar nossa conclusão acerca do termo superação (Überwindung) apresentando certas lacunas que enfraquecem e dificultam à assunção da resignificação do termo supracitado. A resignificação que Heidegger dá ao 
termo superação não encontra respaldo nem em uma semântica nem em uma sintaxe originária. Até onde sabemos não se trata de uma palavra da origem do pensamento ao qual se poderia estabelecer uma reapropriação do seu sentido originário, de modo a servir como critério de sustentação para a referida resignificação e, deste modo, representar suficientemente o projeto do filósofo, naquilo a que o termo em si poderia nos remete e nos comunicar.

Diferentemente do termo Überwindung, a famosa virada (Kehre) nos parece poder expressar o movimento que se realiza no pensamento de Heidegger com menos espaço para mau entendimento. No texto Carta sobre o humanismo de 1946, Heidegger faz referência à virada (Kehre), operada em seu pensamento depois da publicação de Ser e Tempo.

O termo Kehre que comumente é traduzido por "virada" ${ }^{20 "}$ permite estabelecer um espaço de interpretação na via pretendida por Heidegger, sem incorrer em dificuldade de adequação para a ambiguidade que o projeto heideggeriano comporta em si. O Termo Kehre enquanto virada, ao mesmo tempo em que pode apontar para outra direção, comporta a interpretação da virada sob si mesma. Em ambos os caso trata-se de uma virada. Ou seja, a virada comporta a referência ao que lhe é externo, mas também ao que lhe é interno, isto é, ao que é referente a si mesma. A virada promove uma desestruturação de si, tanto em relação ao novo para o qual aponta quanto em relação a si mesma que experimenta o acontecimento da virada. A virada, neste sentido, pode retratar o distanciamento do pensar que sai do jugo da metafísica, na medida em que a virada aponta em outra direção, mas sem abandoná-la na medida em que a virada pressupõe o virar-se sobre si mesma.

\section{Considerações finais}

Caracterizamos a metafísica como ponto de encontro entre Heidegger e Carnap. Pontuamos não haver divergência entre ambos, pois interpretam a metafísica como âmbito do conhecimento da essência das coisas que transcende ao conhecimento das ciências fundadas empiricamente. Ressaltamos que ambos propuseram a superação da metafísica e discutiram sobre os problemas nela existente, mas divergiram significativamente na pretensão estabelecida com a superação da metafísica.

Vimos que Carnap objetivou a superação da metafísica na pretensão de negativizar e refutar a metafísica ao considerá-la de conteúdo fictício e desprovido de qualquer validade. Dissemos que Heidegger, ao contrário, expressou seu posicionamento em 
defesa da metafísica, considerando-a um saber que transcende a causa material e, por isto, nem a lógica matemática e nem as ciências exatas seriam capazes de decidir coisa alguma sobre o seu conteúdo. Destacamos neste posicionamento o objetivo de Heidegger em questionar o império da lógica e das ciências exatas, enquanto Carnap estava empenhado em defender sua autoridade e primazia.

Problematizamos a escolha de Heidegger em nomear seu projeto filosófico com o termo superação da metafísica (Überwindung der Metaphysik), o mesmo utilizado por Carnap. Defendemos que o significado do termo superação (Überwindung) se adéqua propriamente ao propósito de Carnap e não suficientemente ao propósito de Heidegger.

Defendemos a palavra "virada" (Kehre), como termo que suficientemente comunica a pretensão de Heidegger para o projeto filosófico que intentou nos textos da maturidade.

\section{NOTAS}

\footnotetext{
${ }^{1}$ Professor Adjunto de Filosofia pela Universidade do Estado da Bahia (UNEB). Doutor em Filosofia pela Universidade Federal da Paraíba (UFPB). E-mail: fosilva@uneb.br.

2 "Há uma ciência que contempla o Ente enquanto ente e que lhe corresponde a seu ser. Esta ciência não se identifica com nenhuma das que chamamos ciências particulares, pois nenhuma delas especula em geral acerca do Ente enquanto ente, senão que, separando e investigando os entes em partes, levam em consideração seus acidentes; por exemplo, as ciências matemáticas”. (ARISTÓTLES, 1980, p. 150, tradução nossa).

3 "E também é justo que a Filosofia seja chamada ciência da verdade; pois o fím da ciência teórica é a verdade, e o da ciência prática, a obra" (ARISTÓTELES, 1980, p. 86, tradução nossa).

4 "E tantas são as partes da Filosofia quantas são as substâncias. Portanto, uma delas será necessariamente Filosofia primeira, e outra Filosofia segunda". (ARISTÓTELES, 1980, p. 155, tradução nossa).

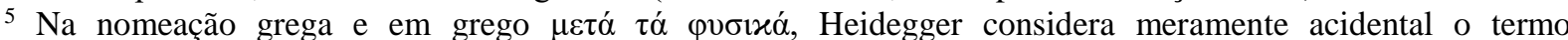
"metafísica" ter surgido pela primeira vez por ocasião da publicação dos livros de Aristóteles por Andrônico de Rodes, que objetivava demarcar os livros que compõem os escritos após os livros da física, sendo esta a explicação dada para utilização da partícula meta na palavra metafísica. Conforme Reale, não se pode atribuir certeza a essa nomeação puramente acidental. Segundo este especialista em Filosofia Antiga, se tem notícia que a expressão metà-tà-physikà já teria ocorrido em ambiente aristotélico, provavelmente com significado específico para aqueles que sucederam Aristóteles em época anterior ao de Andrônico, responsável pela organização e publicação dos livros de Aristóteles (REALLE, 1997. p. 04-07, tradução nossa). Kant também defendeu o caráter não acidental da expressão metafísica, alegando tamanha precisão com a qual o termo define a ciência designada ao colocar de um lado a Physis em referência à natureza e do outro lado a metafísica que fornece os conceitos da natureza mediante a experiência, como ciência que se encontra fora do território da física e para além dela (FICARA 2010, p. 191-192, tradução nossa).

6 "Por isso os principios dos entes eternos são sempre, necessariamente, os mais verdadeiros (pois não são temporariamente verdadeiros, e não há nenhuma causa de seu ser, senão que eles são causa do ser para as demais coisas)". (ARISTÓTELES, 1980, p. 87, tradução nossa).

7 Uma versão do texto para o português brasileiro consta na Revista Cognitio, São Paulo, v. 10, no 2, p. 293-309, jul./dez. 2009, traduzido por William Steinle da versão inglesa The Elimination of Metaphysics Through Logical Analysis of Language (in Logical Positivism (1959), editado por Alfred Ayer), elaborada por Arthur Pap e autorizada pelo autor, Rudolf Carnap (1891-1970). O tradutor alega que a tradução feita a partir da versão em inglês deve-se ao fato dela ter sido bem mais difundida e popularizada do que a original, além do fato de constar a seção 5 e as observações finais que não constam no texto original em alemão.

${ }^{8}$ Sobre o termo Aufhebung de Hegel consultar as indicações de José Pinheiro Pertile: Hegel, Wissenschaft der Logik I, Hegel Werke Suhrkamp Bd. 5 (1983): “Anmerkung. Der Ausdruck: Aufheben”, p. 113-115. Tradução em espanhol de A. e R. Mondolfo (1956), p. 138-139, tradução em francês de P.-J. Labarrière e G. Jarczyk (1972),
} 
p. 81-82; tradução em inglês de G. di Giovanni (2010), p. 81-82; tradução em português de M. A. Werle (2011), p. 98-99. (PERTILLE, 2001, p. 59).

9 Posições fundamentais sobre as quais Heidegger desenvolve seu pensamento: o ser como verdade inquestionável que guia, possibilita e instaura mundo, devendo-se entender a concepção de ser como fundo para tudo que experimentamos, pensamos, temos experimentado, pensado e vivido; os filósofos são aqueles que, atentos à correspondência ser e mundo, ouvem o apelo do ser e sobre ele se pronunciam; o caráter histórico dos conceitos e fundamentos da metafísica não pertence a este ou aquele homem, dão-se como pronunciamento do ser. Para Heidegger, o ser determina homem e mundo em seu acontecimento conjunto e indissociável para além do que a metafísica tradicional é capaz de pensar.

${ }^{10}$ Publicado na revista Erkenntnis, v. II em 1932.

${ }^{11} \mathrm{O}$ termo neokantismo ou neocriticismo nomeia a corrente filosófica desenvolvida principalmente na Alemanha a partir de meados do século XIX até os anos de 1920. Ela defendia o retorno aos princípios de Kant, opondo-se ao idealismo objetivo de Hegel predominante e a todo tipo de metafísica. Para além dessas objeções se colocava, ainda, contra o cientificismo positivista e sua visão absoluta da ciência. O Retorno a Kant (Zurück zu Kant) era a palavra de ordem com vistas ao aprofundamento da filosofia kantiana.

${ }^{12} \mathrm{O}$ artigo A metafísica na ciência moderna: Uma discussão heideggeriana (SILVA, 2015) desconstrói alguns argumentos que tentam inviabilizar a interpretação da Critica da Razão Pura como metafísica.

${ }^{13}$ Heidegger inicia a introdução do livro Kant y el problema de la metafísica com a seguinte afirmação: "A seguinte investigação se propõe a tarefa de interpretar a Crítica da Razão Pura de Kant como uma fundamentação da metafísica. O problema da metafísica se enfoca, pois como problema de uma ontologia fundamental." (HEIDEGGER, 1996, P. 11, tradução nossa).

${ }^{14}$ Ao tempo em que escreveu o texto Kant e o problema da metafísica, Heidegger considerava a Crítica da Razão Pura como fundação da metafísica no sentido de uma metafísica originária, isto é, radical em relação à metafísica tradicional.

15 "O texto de Kant foi o recurso de onde extrai - no próprio Kant - um porta-voz para a questão ontológica por mim levantada" (HEIDEGGER, 1996, p. 07, tradução minha).

${ }^{16}$ Heinrich Gomperz: filósofo austríaco de tendência positivista, elaborou o método patempírico (redução dos conceitos de substância, identidade, relação e forma e experiências, a simples sensações).

Karl Bühler: psicólogo, linguista e filósofo alemão.

${ }^{17}$ Essa passagem foi retirada na versão publicada de 1953.

${ }_{18}$ Em glossário na obra Nietzsche - Metafísica e Niilismo. Assim como fez o tradutor da referida obra, outros estudiosos se esmeraram na tentativa de justificar o referido termo Überwindung.

${ }^{19}$ Original quando, por exemplo, Heidegger resignifica e passa a utilizar uma palavra na pretensão de estar restituindo o seu significado original em lugar da sua significação moderna. Originário quando, por exemplo, resignifica uma palavra considerando não apenas o entendimento original a que ela remete, mas considerando aspectos velados e não evidentes mesmo na sua origem.

${ }^{20}$ Literalmente Kehre significa "virar", no sentido de levar para outra posição ou outra direção. (INWOOD, 2002 , p. 202). Heidegger (2007, p. 507) esclarece: "A virada não é nenhuma inversão, ela é um voltar-se para o interior do outro fundamento como ab-ismo (ausência de fundamento)." Conforme já dissemos, essa virada tanto comporta o virar-se para outra posição como o virar-se sobre si mesmo.

\section{REFERÊNCIAS BIBLIOGRÁFICAS}

ARISTÓTELES. Metafísica. Trad. Valentin Garcia Yebra. Edição trilingüe. Madrid: Gredos, 1987.

CARNAP R. A superação da metafísica pela análise lógica da linguagem. Trad. William Steinle da versão inglesa. In Cognitio, São Paulo, v. 10, nº 2, jul./dez. 2009, p. 293-309.

FICARA H. Heidegger e Il problema della metafísica. Roma: Casini, 2010.

FRIEDMAN, M. La filosofia al bivio - Carnap, Cassirer, Heidegger (The parting of the ways - Carnap, Cassirer and Heidegger). Trad. para o italiano de M. Mugnai. Milão: Raffaello Cortina, 2004. 
. Overcoming Metaphysics. Carnap and Heidegger. In RONALD N. G. e RICHARDSON A. W. Origins of Logical Empiricism. Minnesota Studies in the Philosophy of Science, University of Minnesota Press, 1996, p. 45-79.

HEIDEGGER, Martin. A caminho da linguagem (Unterwegs zur Sprache). Trad. Marcia de Sá Cavalcante Schuback. Petrópolis, RJ: Vozes; Bragança Paulista, SP: Editora Universitária São Francisco, 2003.

A superação da metafísica (Die Überwindung der Metaphysik) In Nietzsche. Metafísica e Niilismo (Metaphysik und Nihilismus). Trad. Marco Antônio Casanova. Rio de Janeiro: Relume Dumará, 2000.

A superação da metafísica (Überwindung der Metaphysik). In Ensaios e conferências (Vorträge und Aufsätze). Trad. Emmanuel Carneiro Leão et lli. Petrópolis: Vozes, 2001.

Carta sobre o humanismo (Brief über den Humanismus). Trad. Rubens Eduardo Frias. São Paulo: Moraes, 1991.

Kant y el problema de la metafísica (Kant und das Problem der Metaphysik), tradução para o espanhol de Gred Ibscher Roth. México: Fondo de Cultura Econômica, 1996a.

Nietzsche I, II. (Nietzsche I, II). Trad. Marco Antônio Casanova. Rio de Janeiro: Forense Universitária, 2007.

Que é metafísica? (Was ist Metaphysik?). Trad. Ernildo Stein. Coleção Os pensadores. São Paulo: Nova Cultural, 1996. 1998.

Ser e Tempo I, II (Sein und Zeit). Trad. Márcia de Sá Cavalcante. Petrópolis: Vozes,

KANT, Immanuel. Crítica da Razão Pura (Kritik der Reinen Vernunft). Trad. Manuela Pinto dos Santos e Alexandre Fradique Morujão. Lisboa: Fundação Calouste Gulbenkian, 1994.

INWOOD, Michael. Dicionário Heidegger. Trad. Luisa Buarque de Holanda. Rio de Janeiro: Jorge Zahar, 2002.

REALLE. G. Guida Allá lettura della “Metafisica” di Aristotele. Roma: Laterza, 1997.

SILVA F.O. A metafísica na ciência moderna: uma discussão heideggeriana. In Revista de Filosofia Aufklärung, João Pessoa, v. 02, nº 02, out.2015, p. 185-206.

PERTILLE, José Pinheiro. Aufhebung meta-categoria da lógica hegeliana. In REH Revista Eletrônica Estudos hegelianos, v.01, nº 15, Jul/dez 2001, p. 58-66. 